\title{
Mitigating Effect of Vardenafil against Colchicine- Induced Testicular Toxicity in Adult Male Albino Rats Authors
}

\author{
Mohamed F. Abbas, Osama A. Hassan', and Hasan El-Fakahany² \\ ${ }^{\mathbf{1}}$ Department of Forensic Medicine \& Clinical toxicology, Minia University, Minia, Egypt. \\ ${ }^{2}$ Department of Dermatology, STD’s 7\& Andrology, STD’s 7\& Andrology, Minia University, Minia, Egypt.
}

\begin{abstract}
Vardenafil is a phosphodiesterase-5 inhibitor, preserving and increasing the levels of cGMP (cyclic guanosine monophosphate) in soft muscle of the penis and increasing the erection duration. These vasodilators have protective effects on vascular structures. In this study we evaluated the effect of vardenafil on testicular toxicity induced by colchicine in rats.

Forty male adult albino rats were divided into 4 groups of 10 animals each. First group(control) received $1 \mathrm{ml}$ of distilled water orally and injected with $0.2 \mathrm{ml}$ saline subcutaneously (s.c.), second group (Vardenafil) received $1 \mathrm{mg} / \mathrm{kg} /$ day vardenafil orally, third group (Colchicine) received 25 $\mathrm{mg} / \mathrm{kg} / \mathrm{day}$ of colchicine s.c. and fourth group (Colchicine + Vardenafil) received $25 \mathrm{mg} / \mathrm{kg} /$ day colchicine s.c. with vardenafil $1 \mathrm{mg} / \mathrm{kg} /$ day orally. The period of the experimental study extended to 28 days. At the end of the study the rats and testes were weighed and testicular toxicity was evaluated by investigating seminal parameters and testicular histopathological changes. Administration of colchicine led to significant decrease in sperm count, motility and viability with significant increase in abnormal sperm forms when compared to control group rats. There was non-significant change regarding both body and testicular weights after administration of colchicine when compared to control group rats. Histopathological changes showed damaged seminiferous tubules, depletion of spermatogenic cells with disruption and thickening of the basement membrane. Some tubules became shrunken and filled with debris of shedded cells and arrested spermatogenesis was noticed in scattered tubules with spermatogenic vacuolations and degenerated mitochondria. Administration of vardenafil with colchicine led to significant decrease of colchicine side effects on seminal parameters and testicular histopathological changes. It is concluded that treatment with vardenafil limits testicular toxicity induced by colchicine.
\end{abstract}

Keywords Vardenafil, PDEI, Colchicine, Testis

\section{Introduction}

Phosphodiesterase inhibitors (PDEIs) are a widely used group of oral therapy for Erectile Dysfunction (ED). This group is selective for cyclic guanosine monophosphate-specific phosphodiesterase (PDE) type 5 present in corpora cavernosa (Lombardi et al, 2012). The group has 3 major members: sildenafil, vardenafil, and tadalafil. These agents have been shown to possess antioxidative or oxidative stress-protective properties (Puerta et al, 2012).

Vardenafil is a potent PDE5 inhibitor that was Food and Drug Administration (FDA) approved to treat erectile dysfunction in 2003. Its chemical structure is very similar to that of sildenafil; however, it boasts a superior potency and selectivity compared with sildenafil (Kuthe, 2003). 
Colchicine is used for the treatment of gout, familial Mediterranean fever, primary biliary cirrhosis, amyloidosis and condyloma acuminata. Despite its merits, it has a narrow therapeutic index, with no clear-cut distinction between nontoxic, toxic, and lethal doses, causing substantial confusion among clinicians. (Filkenstein et al, 2010).

Gout is a chronic disease and needs repeated doses of colchicine over a long period inducing multiorgan dysfunction if it is given inadvertently in high doses exceeding the recommended dose (Wagenaar, 2004).

However, colchicine is still an important treatment option as it is particularly useful for patients with co-morbidities, such as diabetes, renal impairment and peptic ulcer disease, in whom NSAIDs and prednisone may cause significant adverse effects (Dalbeth and Gow, 2011).

It is generally assumed that acute toxicity by colchicine is an emergency in clinical toxicology. Rapid diagnosis and treatment can prevent death. The most common causes of death in this toxicity are acute cardiac failure, shock, and dysrhythmias with hematopoietic complications occurring in later stages (Aghabiklooei et al, 2014).

The present study aimed to investigate the modulating effect of vardenafil on testicular toxicity of colchicine.

\section{Material and methods}

The present study was carried out in Forensic Medicine \& Clinical Toxicology and Dermatology, STD's \& Andrology Departments, Faculty of Medicine, Minia University after the approval of the Ethical Committees. Promotion of a high standard of care and animal well-being at all times was done. Scarifications and all painful procedures were performed under ether inhalation anesthesia to avoid distress and pain. Our standards of animal care and administration met those required by applicable international laws and regulations.

\section{Drugs}

Levitra ${ }^{\circledR}$ tablets of Bayer Co. (Vardenafil 20 mg per tablet) were crushed and dissolved in distilled water for oral administration. Colchicine was obtained from ElNasr Pharmaceutical Chemicals Co. (ADWIC). It is available as white powder (1g) in dark bottles and dissolved in saline $0.9 \%(25 \mathrm{mg} / \mathrm{ml})$. The animals were observed daily for clinical signs of toxicity and mortality. Body weight and food consumption were recorded once weekly.

\section{Animals}

Forty adult male albino rats with an average weight of 200 g each. They were obtained from the animal house, Faculty of Medicine, Minia University. Rats had acclimatized for two weeks and were caged (5 / cage) in fully ventilated room and at room temperature. Rats had free access to standard laboratory food and water during the experimental period. They were divided into four groups of 10 animals each.

Group 1(control group): were given $1 \mathrm{ml}$ of distilled water by gavage and injected with $0.2 \mathrm{ml}$ saline subcutaneously (s.c.) for 28 days.

Group 2 (vardenafil group): were given $1 \mathrm{mg} / \mathrm{kg}$ vardenafil(Hatice et al, 2013)orally once daily for 28days

Group 3 (colchicine group): were given $25 \mathrm{mg} / \mathrm{kg}$ colchicine s.c.(Almiron and Chemes, 1988) once daily for 28 days.

Group 4 (colchicine + vardenafil): were given 25 $\mathrm{mg} / \mathrm{kg}$ colchicine s.c. with vardenafil $1 \mathrm{mg} / \mathrm{kg}$ orally once daily for 28 days.

After the last dose, the animals were sacrificed and laparotomy was conducted to obtain theepididymes and testes. The epididymis was processed for the evaluation of sperm parameters. Testes were weighed in grams (absolute organ weight). The relative organ weight was calculated as follows:

Relative organ weight $=$ absolute weight $(\mathrm{g})+$ 100/body weight of rat on sacrifice day (g). Then, the testes were fixed in Bouin's solution for further processing for histopathological examination.

\section{Sperm count, motility viability and morphology}

The epididymis was removed, cleaned off from the epididymal fat pad, minced in $1 \mathrm{ml}$ of prewarmed $\left(35^{\circ} \mathrm{C}\right)$ phosphate- buffered saline(PBS, $5 \mathrm{ml}$ $\mathrm{g}^{-1}$ testis $\left.\mathrm{pH} 7.35\right)$ and filtered through $80 \mu \mathrm{m}$ pore-size mesh. The filtrate was used for the evaluation of epididymal sperm parametersaccording to WHO(2010)as follows.

(a) Sperm count

The filtrate was taken in a leukocytic hemocytometer up to mark 0.5 and then diluted with PBS up to mark 11. An aliquot of this suspension was charged into the Neubauer's counting chamber and sperms were counted. The sperm count was expressed in millions per milliliter.

(b) Sperm motility

One hundred sperms each were observed in three different fields, and classified into motile and non-motile. Motility was expressed as percentage incidence.

(c) Sperm morphology and viability

Smears of sperm suspensions were stained with periodic acid-Schiff's reaction and haematoxylin. The stained smears were examined under light microscope with 40 objective lens (to determine the percentage of sperm cell viability and morphological abnormalities) and sperm were classified into normal and abnormal. The total sperm abnormality was expressed as percentage.

Histopathological examination

The testes, after being fixed in Bouin's solution, were embedded in paraffin wax, and then sections of $5 \mu$ thickness were stained with haematoxylin and eosin (H\&E). Microscopic examination with light microscope was performed (Drury and Wallingaton, 1980). Digital images were then obtained (ORCA II cooled CCD camera mounted on an BX60 microscope; Olympus, Lake Success, NY, 
USA). Images were acquired in image-analysis software (Photoshop ver. 7.0; Adobe Systems Incorporated, San Jose, CA, USA), and minimal adjustments were made to the figure contrast to obtain the best micrograph.

Ultrastructural studies were done by Transmission Electron Microscope (TEM). Testicular tissue was cut into small pieces $1 \mathrm{~mm}$ thick and fixed in $4 \%$ formaldehyde in phosphate buffer solution $(\mathrm{pH}$ 7.2) for 3 hrs. at $4{ }^{\circ} \mathrm{C}$, after which the tissues were removed and post fixed in buffered $2 \%$ osmium tetroxyde for one hour at $4^{\circ} \mathrm{C}$. Post fixed tissues were rinsed in the buffer and dehydrated at $4^{\circ} \mathrm{C}$ through a graded series of ethanol. Then they were embedded in Epon Araldite mixture in labeled beam capsules. Ultrathin sections (50 nm thick) were cut, collected on naked copper-mesh grids and stained with uranyl acetate for 10-15 min and lead citrate for 5-10 min (Bancroft and Gamble, 2002).

Statistical analysis

Data were checked, coded, entered and analyzed using SPSS (version 20.0 software) (University of Nevada, Las Vegas, NV, USA). The results were expressed as means \pm SD on Microsoft Excel 8.0. Comparison between the means of different groups was made using student $(\mathrm{t})$ test for independent samples. Chi-Square statistical analysis was done for histopathological changes. Significance was assured at $\mathrm{P}<0.05$.

\section{Results}

\section{Body and Testicular weight changes}

There wasnon-significant change between all four groups when compared to each other regarding both body and testicular weights.

Sperm parameters(table 1)

Group 2 (vardenafil group) showed no -significant change in sperm count, motility, viability and abnormal sperm forms when compared with control group.

On the other hand there was significant decrease $(\mathrm{P}<$ 0.05) in sperm count, motility and viability and significant increase $(\mathrm{P}<0.05)$ in abnormal sperm forms in colchicine group rats when compared to both control and vardenafil groups.

Group 4 (colchicine + vardenafil) showed significant increase $(\mathrm{P}<0.05)$ in sperm count, motility and viability and significant decrease in abnormal sperm forms when compared to colchicine group.

However there was significant decrease $(\mathrm{P}<0.05)$ in sperm count, motility and viability with significant increase $(\mathrm{P}<0.05)$ in abnormal sperm forms in group 4 (colchicine + vardenafil) rats when compared to both control and vardenafil groups.

\section{Histopathological changes}

Testicular histopathological findings by light microscope:Histological examination of testes of control and vardenafil groups showed normally shaped rounded seminiferous tubules separated by a thin intertubular connective tissue with Leydig cells and normal arrangement of the spermatogenic layers. The sperms were situated in the lumen of the tubule and facing towards the Sertoli cells (Fig. 1, a).On the other hand, testes of group 3 (colchicine) revealed severely damaged seminiferous tubules, depletion of spermatogenic cells with disruption of the basement membrane. Some tubules became shrunken and filled with debris of shedded cells. Arrested spermatogenesis was noticed in scattered tubules (Fig. 1, b \&c)and table (2).

Group 4 (colchicine + vardenafil) revealed mild degenerative changes in few seminiferous tubules, some seminiferous tubules with continuous spermatogenesis and others contain necrotized epithelium. In other words, (colchicine + vardenafil) group showed improvement of testicular histology compared to colchicine group with nearly normal germ cells lining seminiferous tubules with increased number of sperms, nearly normal interstitial cells of Leydig and basement membrane (Fig.1, d) and table (2).

Testicular histopathological findings by semithin section:Testes of control and vardenafil groups showed normal seminiferous tubule with different stages of spermatogenic cells and normal basement membrane. The interstitial cells have pale stained nucleus and cytoplasm. (Fig. 2, a). On the other hand, testes of group 3(colchicine) revealed marked vacuolations within and in between the spermatogenic cells. The basement membrane is markedly thickened and highly folded. Interstitial cells have darkly stained cytoplasm and nuclei. There was depletion of spermatogenic cells (Fig. 2, b\& c) and table (3) .Group 4 revealed minimal vacuolation and slight thickening of the basement membrane and apparently normal spermatogenic cells. (Fig. 2, d) and table (3).

Testicular histopathological findings by electron microscope:The testes of colchicine group revealed thickening of the basement membrane with irregular wavy appearance, folded nuclear envelop of Sertoli cells with heterochromatin clumps, degenerated spermatogonia, vacuolations, degenerated mitochondria and fragmented spermatozoa (Fig.3,a, b and c) and table (3).

Group 4 revealed improvement of histopathological changes of testicles with nearly normal spermatogenic cells (Fig. 3, d) and table (3).

Figure (1) :-

a) Control and Vardenafil groups showing the seminiferous tubules (st) lined by regularly arranged rows of spermatogenic cells. The interstitial cells of Leydig (ic) located between the seminiferous tubules. Inset key (1.mature sperms 2.spermatid 3.primary spermatocytes 4.spermatogonium 5.myoid cell). ).

b)Colchicine group showing degenerative changes in seminiferous tubules (star).

c) Colchicine group showing severely damaged seminiferous tubules. Depletion of spermatogenic cells with disruption of the basement membrane (black arrow). Some tubules became 
shrunken filled with debris of shedded cells (green arrow). Arrested spermatogenesis was noticed in scattered tubules (double headed arrow). Inset showing spermatogenic cells in the interstitial tissue (broad arrow).

d) Vardenafil plus colchicine treated group showing mild degenerative changes, some seminiferous tubules with continuous spermatogenesis (arrow). Others contain few necrotized epithelium (arrow head).

Figure (2) :-

a) Control and Vardenafil groups showing normal seminiferous tubule withdifferent stages of spermatogonic cells (arrows) and thin basement membrane (BM). The interstitial cells (IC) have pale stained nucleus and cytoplasm. .

b)Colchicine group showing vacuolation (arrow) and thickening of the basementmembrane.

c) Colchicine group showing marked vacuolations within and in between the spermatogenic cells (arrows). The basement membrane is markedly thickened and highly folded. Interstitial cells have darkly stained cytoplasm and nucleiwith depletion of spermatogenic cells.

d) Vardenafil plus colchicine treated group showing mildly thickened basement membrane, mild vacuolations (V), apparently normal spermatogenic cells (arrows).

Figure (3) :-

a,b,c) Colchicine group showing thickening of the basement membrane with irregular wavy appearance (BM), folded nuclear envelop of Sertoli cells (S), with heterochromatin clumps (arrows), degenerated spermatogonia (SG), vacuolations (V), lysosome and phagolysosome (L), spermatid (SD), degenerated mitochondria (m), fragmented spermatozoa (SZ).

d)Colchicine plus vardenafil treated group showing myoid cell (M) and normal spermatogenic cells.

Table (1): Student (t) test analysis of body weight, testicular weight and sperm parameters among the studied groups of adult male albino rats (10 rats each).

\begin{tabular}{|l|l|l|l|l|}
\hline \multicolumn{1}{|c|}{ Groups } & \multicolumn{1}{c|}{$\begin{array}{c}\text { Control } \\
\text { Parameters }\end{array}$} & $\begin{array}{c}\text { Vardenafil } \\
\text { (II) }(1 \mathrm{mg} / \mathrm{kg} \text { oral) }\end{array}$ & $\begin{array}{c}\text { Colchicine }+ \\
\text { Colchicine } \\
\text { (III)(25mg/kg s.c.) }\end{array}$ & $\begin{array}{c}\text { Vardenafil } \\
\text { (IV) (25mg/kg s.c. }+ \\
(\mathrm{mg} / \mathrm{kg} \text { oral) }\end{array}$ \\
\hline Body weight (g) & $201.5 \pm 3.02$ & $202 \pm 1.07$ & $202 \pm 2.22$ & $200.6 \pm 2.11$ \\
\hline Testicular weight (g) & $1.7 \pm 0.36$ & $1.67 \pm 0.23$ & $1.59 \pm 0.17$ & $1.59 \pm 0.46$ \\
\hline Sperm count (million/ml) & $14.32 \pm 1.20$ & $15.13 \pm 1.78$ & $4.15 \pm 0.26 \mathrm{a}$ & $7.36 \pm 0.21 \mathrm{a}, \mathrm{b}$ \\
\hline Sperm motility (\%) & $71.12 \pm 2.30$ & $70.23 \pm 2.41$ & $50.16 \pm 0.34 \mathrm{a}$ & $61.24 \pm 0.24 \mathrm{a}, \mathrm{b}$ \\
\hline Sperm abnormality (\%) & $4.61 \pm 0.22$ & $5.15 \pm 0.47$ & $23.11 \pm 0.25 \mathrm{a}$ & $17.62 \pm 0.19 \mathrm{a}, \mathrm{b}$ \\
\hline Sperm viability (\%) & $82.61 \pm 2.79$ & $80.98 \pm 2.14$ & $61.72 \pm 1.4 \mathrm{a}$ & $76.61 \pm 1.68 \mathrm{a}, \mathrm{b}$ \\
\hline
\end{tabular}

Data were presented as Mean $\pm S D$, a: Significant difference $(P<0.05)$, when compared to control group,

$b$ : Significant difference $(P<0.05)$, when compared to colchicine group.

Table (2): Chi-Square statistical analysis of light microscopic findings among the studied groups of adult male albino rats (10 rats each).

\begin{tabular}{|c|c|c|c|c|c|}
\hline $\mathrm{C}_{\text {Changes }}^{\text {Groups }}$ & $\begin{array}{l}\text { Control } \\
\text { (I) }\end{array}$ & $\begin{array}{l}\text { Vardenafil } \\
\text { (II) }(1 \mathrm{mg} / \mathrm{kg} \\
\text { oral })\end{array}$ & $\begin{array}{l}\text { Colchicine } \\
\text { (III) }(25 \mathrm{mg} / \mathrm{kg} \\
\text { S.c. })\end{array}$ & $\begin{array}{c}\text { Colchicine }+ \\
\text { Vardenafil } \\
\text { (IV) }(25 \mathrm{mg} / \mathrm{kg} \text { s.c. }+ \\
1 \mathrm{mg} / \mathrm{kg} \text { oral })\end{array}$ & $\begin{array}{c}\text { Chi- } \\
\text { square }\end{array}$ \\
\hline $\begin{array}{l}\text { 1- Depletion of } \\
\text { spermatogenic cells }\end{array}$ & $\begin{array}{c}0 \\
0 \% \\
\end{array}$ & $\begin{array}{c}0 \\
0 \% \\
\end{array}$ & $\begin{array}{c}8 \\
80 \% \\
\end{array}$ & $\begin{array}{c}2 \\
20 \% \\
\end{array}$ & $\begin{array}{l}\mathrm{X}^{2}=29.3 \\
\mathrm{P}=0.001^{*}\end{array}$ \\
\hline $\begin{array}{l}\text { 2- Degenerative changes in } \\
\text { seminiferous tubules }\end{array}$ & $\begin{array}{c}0 \\
0 \%\end{array}$ & $\begin{array}{c}0 \\
0 \%\end{array}$ & $\begin{array}{c}9 \\
90 \%\end{array}$ & $\begin{array}{c}3 \\
30 \%\end{array}$ & $\begin{array}{l}\mathrm{X}^{2}=30.1 \\
\mathrm{P}=0.001\end{array}$ \\
\hline $\begin{array}{l}\text { 3- Disruption of the basement } \\
\text { membrane }\end{array}$ & $\begin{array}{c}0 \\
0 \%\end{array}$ & $\begin{array}{c}0 \\
0 \%\end{array}$ & $\begin{array}{c}7 \\
70 \%\end{array}$ & $\begin{array}{c}2 \\
20 \%\end{array}$ & $\begin{array}{l}X^{2}=27.3 \\
P=0.001^{*}\end{array}$ \\
\hline 4- Arrested spermatogenesis & $\begin{array}{c}0 \\
0 \%\end{array}$ & $\begin{array}{c}0 \\
0 \%\end{array}$ & $\begin{array}{c}8 \\
80 \%\end{array}$ & $\begin{array}{c}2 \\
20 \%\end{array}$ & $\begin{array}{l}X^{2}=29.3 \\
P=0.001 *\end{array}$ \\
\hline
\end{tabular}

* = Significant at $(P<0.05)$ 
Table (3): Chi-Square statistical analysis of electron microscopic findings among the studiedgroups of adult male albino rats (10 rats each).

\begin{tabular}{|l|c|c|l|}
\hline \multicolumn{1}{|c|}{ Groups } & $\begin{array}{c}\text { Colchicine } \\
\text { (III) }(25 \mathrm{mg} / \mathrm{kg} \\
\text { C.c. })\end{array}$ & $\begin{array}{c}\text { Colchicine + Vardenafil } \\
\text { (IV) (25mg/kg s.c. }+1 \mathrm{mg} / \mathrm{kg} \\
\text { oral) }\end{array}$ & \multicolumn{1}{c|}{$\begin{array}{c}\text { Chi- } \\
\text { square }\end{array}$} \\
\hline 1- Cytoplasmic vacuolations & 9 & 2 & $\begin{array}{l}\mathrm{X}^{2}=31.2 \\
\mathrm{P}=0.001^{*}\end{array}$ \\
\hline $\begin{array}{l}\text { 2- Degenerated } \\
\text { spermatogonia }\end{array}$ & $80 \%$ & $20 \%$ & $\mathrm{X}^{2}=30.8$ \\
\hline 3- Degenerated mitochondria & $80 \%$ & $10 \%$ & $\mathrm{P}=0.001^{*}$ \\
\hline 4- Fragmented spermatozoa & 7 & 2 & $\mathrm{X}^{2}=27.9$ \\
& $70 \%$ & $20 \%$ & $\mathrm{P}=0.001^{*}$ \\
\hline 5- Heterochromatin clumps & $80 \%$ & 2 & $\mathrm{X}^{2}=28.7$ \\
& 6 & $20 \%$ & $\mathrm{P}=0.001^{*}$ \\
\hline
\end{tabular}

$*=$ Significant at $(P<0.05)$
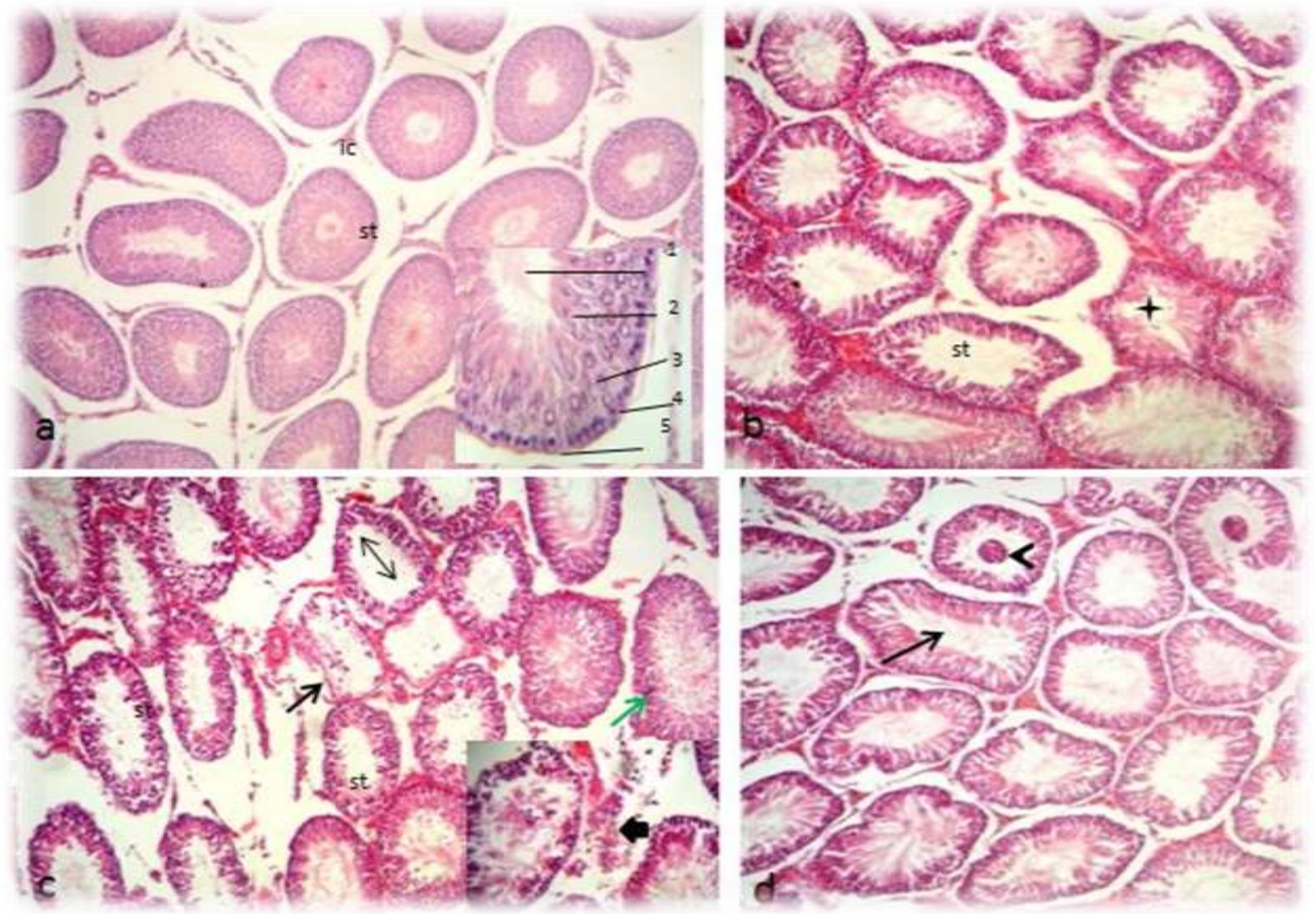

Figure (1): photomicrograph of transverse sections of testis of an adult albino rat stained with $\mathrm{H} \& \mathrm{E}$ (magnification; objective X10) 

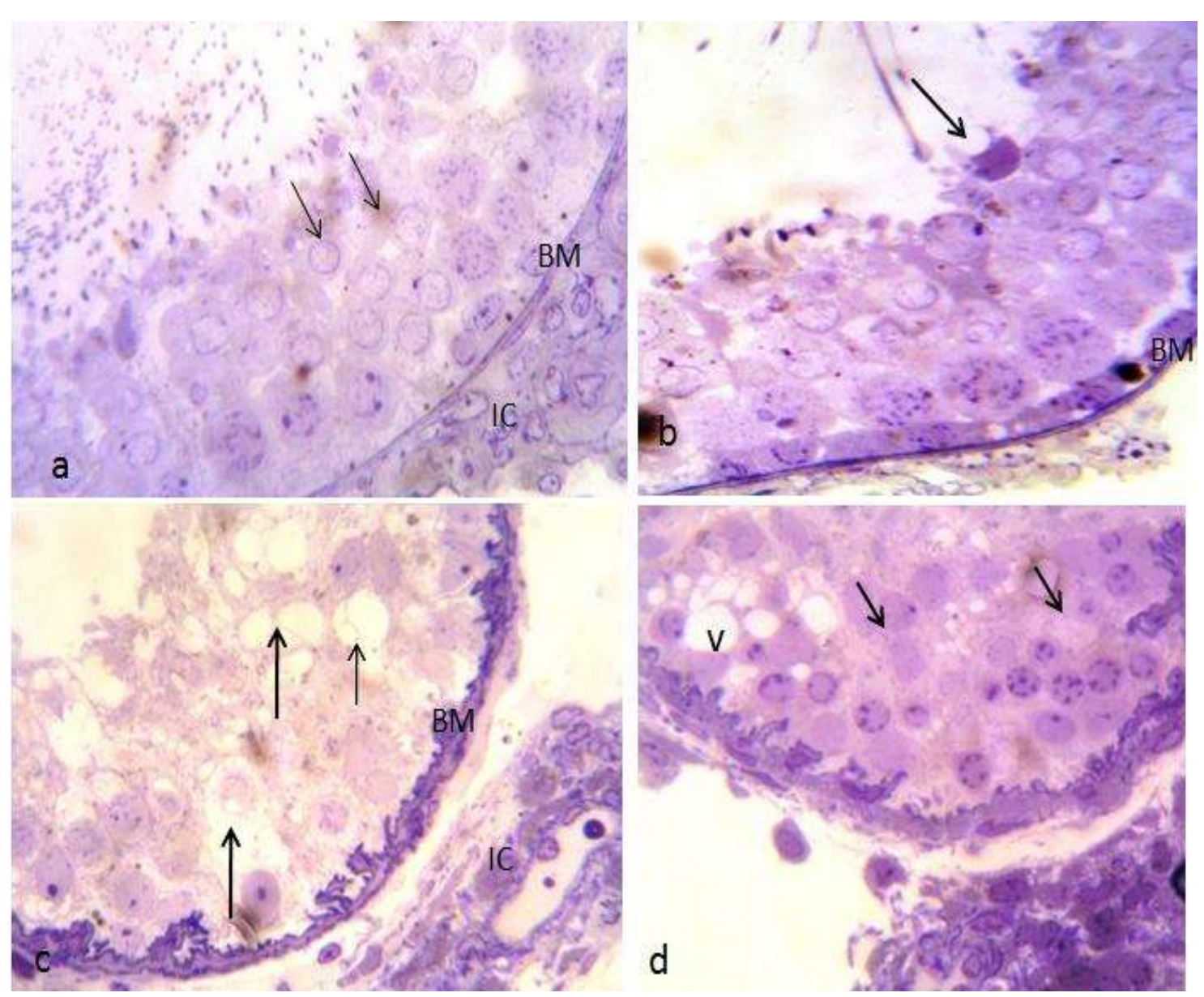

Figure (2): Photomicrograph of a semi-thin section of the testis of an adult albino rat (magnification; objective X100)
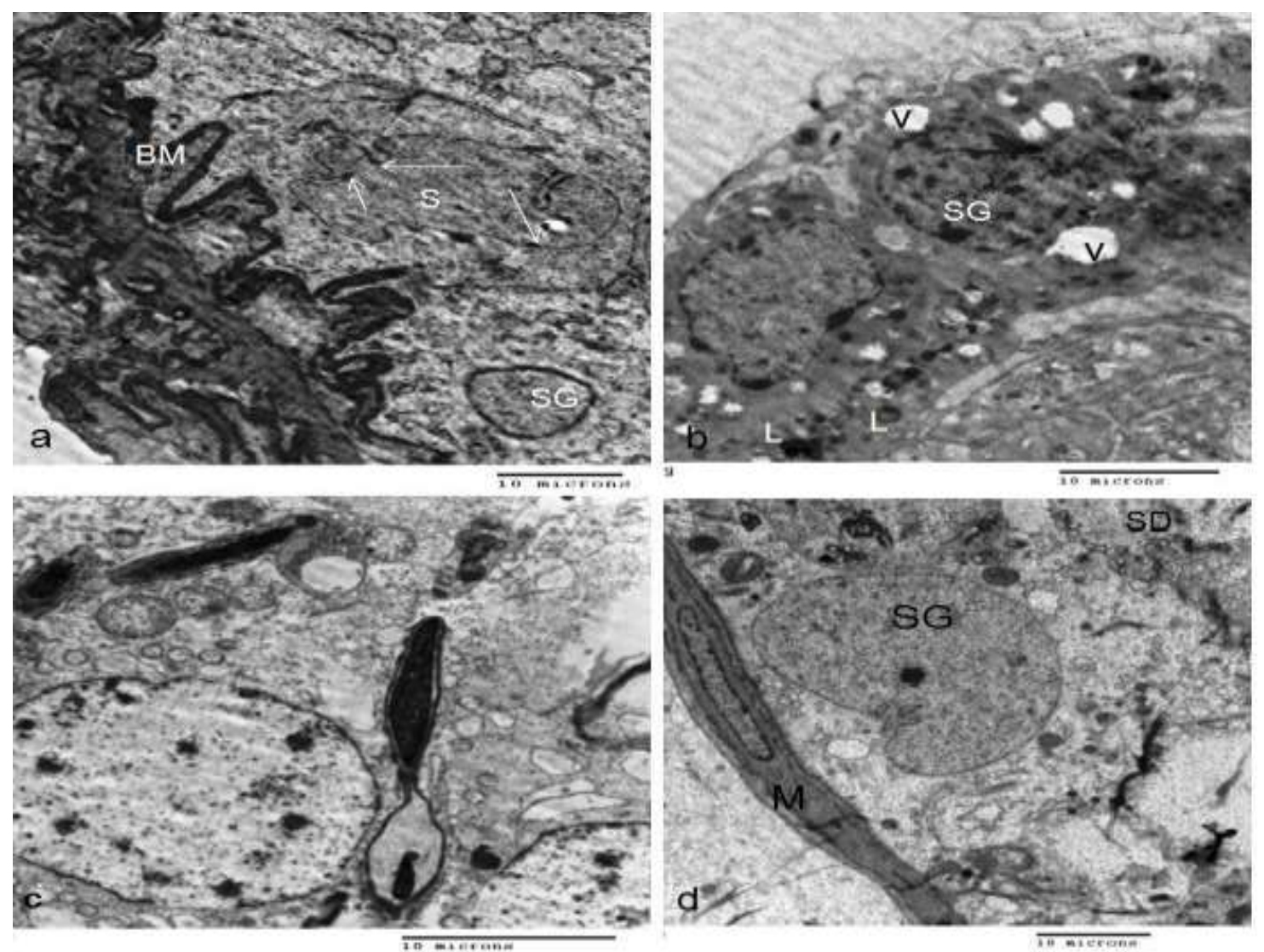

Figure (3): Photoelectron micrograph of transverse section of testis of an adult albino rat 


\section{Discussion}

Vardenafil is a vasoactive drug developed for treatment of erectile dysfunction. It inhibits the phosphodiesterase type -5 (PDE-5) enzyme, which changes cyclic guanosine monophosphate (cGMP) into inactive GMP. The increased levels of cGMP lead to smooth muscle relaxation and vasodilatation (Shabsigh, 2004).

Guanylate cyclase-activating substances, deeply affect sperm motility, capacitation, and acrosomal reactivity, stimulating sperm metabolism and promoting the ability of the sperm to approach the oocyte, interact with it, and finally fertilize it (RevellI et al., 2002).

Colchicinetoxicity is an extension of its mechanism of action - binding to tubulin and disrupting the microtubular network. As a result, affected cells experience impaired protein assembly, decreased endocytosis and exocytosis, altered cell morphology, decreased cellular motility, arrest of mitosis, and interrupted cardiac myocyte conduction and contractility. The culmination of these mechanisms leads to multi-organ dysfunction and failure (Filkenstein et al., 2010).

Sperm morphogenesis is a complex process. Germ and Sertoli cells contain numerous microtubules which are essential for normal morphogenetic processes of spermatogenesis. Colchicine interacts with microtubules inducing sperm structural abnormalities (Hess and Nakai, 2000).

So the present study investigates the role of vardenafil on modulating testicular toxicity induced by colchicine by studying semen analysis and histopathological changes in testicles of adult male albino rats.

The present study demonstrated that administration of colchicine resulted in significant decrease in count, motility and viability of sperms with significant increase in sperm abnormal forms.

Regarding histopathological changes of testicular tissue, our results revealed significant histological changes with damage of seminiferous tubules, depletion of spermatogenic cells, disruption of the basement membrane with some tubules became shrunken and filled with debris of shedded cells,vacuolations within and in between the spermatogenic cells and arrested spermatogenesis was noticed in scattered tubules with degenerated mitochondria.

The present results are in agreement with other studies of Said et al., (2013) andMohanad et al., (2014)about the toxic effect of colchicine on seminal parameters and histopathological changes in rats who found that colchicine toxicity led todamage of seminiferous tubules with germ cell loss and defect of spermatogenesis causing low sperm count, increase of abnormal shaped sperms,decrease of sperm motility and viability.

Administration of vardenafil with colchicine limited significantly adverse effects of colchicine on sperm count, motility, viability and morphology. Some of these results coincided with Rago et al, (2012) who revealed mitigating effect on sperm motility after a single-dose of vardenafil administration and improvement in sperm concentration after 15 days of treatment with vardenafil on alternate days in infertile men.

Also Grammeniatis et al, (2007) stated that semen samples from infertile men treated with vardenafil $10 \mathrm{mg}$ daily for 45 days presented a significantly larger total number of spermatozoa, quantitative sperm motility, qualitative sperm motility and percentage of morphologically normal spermatozoa. They also found increased secretory function of prostate and suggested that vardenafil stimulated the prostatic secretory function increasing the quantitative and qualitative motility of spermatozoa.

Dimitriadis et al, (2010) also found that sperm concentration, percentage of motile spermatozoa, and percentage of morphologically normal spermatozoa were significantly greater after vardenafil and sildenafil treatment in oligoasthenospermic infertile men. They explained these effects by increased serum level of insulin-like-3 peptide indicating increased Leydig cell secretory function (LCSF) and suggested that this enhancement in LCSF might contribute to the increase in sperm concentration and sperm motility after administration of PDE5-i.

On the other hand Bauer and Rohde, (2002) found no statistically significant effects of vardenafil on sperm motility, sperm concentration, viability, and morphology after a single dose of vardenafil $20 \mathrm{mg}$ performed on sixteen healthy males. Moreover, Mohammed, (2014) found significant decrease in sperm count and motility in rats treated with $(20 \mathrm{mg} / \mathrm{kg}$ body weight) of vardenafil for 4 weeks. These results can be explained by the use of a high dose of vardenafil.

The histological damage that occurred in the rat testis after administration of colchicine were also in line with Russell et al, (1981)andAllard et al, (1993)who revealed sloughing of germ cells and attached apical seminiferous epithelium.

Liane et al, (2002) stated that colchicine did cause damage to the mouse seminiferous epithelium, including germ cell sloughing and loss of Sertoli cell microtubules based on the loss of thick bundles or "spokes" of tyrosinated $\alpha$ tubulin and $\beta$ tubulin.

In studies done by Erol et al, (2009) and Hatice et al,( 2013) Administration of $1 \mathrm{mg} / \mathrm{kg}$ vardenafil during testicular and ovarian torsion respectively decreased ischemia/reperfusion cellular damage and improved oxidative stress by significantly decreasing malondialdehyde (MDA) levels that was significantly significantlyincreasedsuperoxide dismutase(SOD), catalase(CAT) and glutathione peroxidase(GPx) activities that weresignificantly decreased after testicular and ovarian torsion, indicating that the reduction in oxidative stress by vardenafil may play a major role in its cytoprotective effects which may be a 
possible mechanism for improvement of histopathological changes and seminal parameters.

\section{Conclusion}

Administration of Colchicine lead to testicular toxicity evident by reduction in sperm count, motility and viability with increased sperm abnormal forms in addition to degenerative histopathological changes. Vardenafil administration decreased these changes and modulates testicular toxicity induced by colchicine

Additional studies are required to confirm the role of vardenafil as a protective agent against other agentinduced testicular toxicity and its mechanismof protection.

\section{References}

Aghabiklooei A, Zamani N, Hassanian-Moghaddam H et al.,(2014): Acute colchicine overdose: report of three cases. Reumatismo17. 65:30711

Allard E K, Johnson K J, and Boekelheide K (1993): Colchicine disrupts the cytoskeleton of rat testis seminiferous epithelium in a stagedependent manner. Biol. Reprod. 48:143153.

Almiron I and Chemes H (1988): Spermatogenic onset. FSH modulates mitotic activity of germ and sertoli cells in immature rats. Int $\mathrm{J}$ Androl. 11:235-246.

Bancroft JD and Gamble M (2002): Theory and practice of histological techniques. $5^{\text {th }}$ ed., Churchill Livingstone Pub. Edinburgh. 172 5:393-620.

Bauer RJ and Rohde GA (2002): single dose of Vardenafil had no acute effect on sperm motility in healthy males. $27^{\text {th }}$ annual meeting of the American Society of Andrology. April 24-27.

Bearden HJ, Fuquary JW, and Willard ST (2003): Applied animal reproduction. 6th; Ed; Reston Publishing Co; Inc; Reston, Virginia, p: 448.

Dalbeth N and Gow P (2011): New Zealand Rheumatology Association. Colchicine prescribing in patients with gout. N Z Med J. 124:107-8.

Dimitriadis F, Tsambalas S, Tsounapi Pet al.,(2010): Effects of phosphodiesterase-5 inhibitors on Leydig cell secretory function in oligoasthenospermic infertile men: a randomized trial. BJU Int. 106:1181-5.

Drury R.A and Wallingaton EA (1980): Carlton histological technique $5^{\text {th }}$ ed. Oxford University Press. London, New York, Toronto.65 -75.

Erol B, Tokgoz H, Hanci Vet al.,(2009): Vardenafil reduces testicular damage following ischemia/reperfusion injury in rats. Kaohsiung J Med Sci. 25:374-80.
Filkenstein Y, Aks SE, Hutson JRet al.,(2010): Colchicine poisoning: the dark side of an ancient drug. Clin Toxicol. 48:407-414.

Grammeniatis E, Kanakas N, Tsounapi Pet al., (2007): Effects of vardenafil in sperm parameters and semen biochemistry. J Androl. 28: 60.

Hatice BAŞ, Özlem KARA, Mustafa KARA andDilek PANDIR (2013): Protective effect of vardenafil on ischemia-reperfusion injury in rat ovary. Turk J Med Sci. 43: 684-689

Hess RA and Naki M (2000): Histopathology of male reproductive system inducedby the fungicide benomyl. Histol. Histopathil. 15:207-224

Kuthe A (2003): Phosphodiesterase 5 inhibitors in male sexual dysfunction. Curr Opin Urol. 13: 405-10.

Liane M, Masaaki N, Christina Set al.,(2002): Microtubules of the mouse testis exhibit differential sensitivity to the microtubule disruptors Carbendazim and Colchicine. Toxicol. Sci. 69:175-182.

Mohammed A.T. (2014): Effect of Vardenafil on fertility in male rats.I.J.S.N. 5:297-303

Mohanad I Shehab, Nasr N Zaki, Mary E Boutroset al., (2014): The possible protective effect of sildenafil on colchicine induced infertility in rats. International Journal of Advanced Rsearch. 2:939-951.

Puerta E, Barros-Minones L, Hervias Iet al., (2012): Long-lasting neuroprotective effect of sildenafil against 3,4methylenedioxymethamphetamine- induced 5hydroxytryptamine deficits in the rat brain. $\mathrm{J}$ Neurosci Res. 90: 518-528.

Rago R, Salacone P, CaponecchiaL et al.,(2012) : Effect of vardenafil on semen parameters in infertile men: A pilot study evaluating shortterm treatment. J Endocrinological Investigation.35:897-900

Revelli A, Ghigo D, Moffa Fet al.,(2002): Guanylate cyclase activity and sperm function. Endocr Rev. 23:484-94.

Russell L. D, Malone J P, and MacCurdy D S (1981): Effect of the microtubule disrupting agents, colchicine and vinblastine, on seminiferous tubule structure in the rat. Tissue Cell. 13: 349-367.

Said S. Elshama, Gaber M. G. Shehab, Ayman E. ElKenawy et al., (2013):Role of Nigella Sativa Seeds on modulation testicular toxicity of colchicine repeated use in adult albino rats.Life Science Journal 10(4): 1629- 17 r 9.

Shabsigh R (2004): Therapy of Erectile Dysfunction (ED): PDE-5 inhibitors. Endocrine. 23: 135141. 
Wagenaar Z. (2004): Accidental colchicine poisoning in a dog. Can. Vet. J. 45 :55-57.
World health organization (2010): WHO laboratory manual for the examination and processing of human semen, $5^{\text {th }}$ ed. Geneva. 21-36.

\section{الملخص العربي}

\section{التأثير الملطف للفردينافيل ضد السمية الخصوية المستحثة بالكولشيسينفى الجرذان البيضاء البالغة}

\section{محمد فتحى عباس و أسامة عبدالعزيز 1 و حسن حسن الفكهانى2}

يعمل عقار الفردينافيل عللالزيادة والحفاظ على مستويات الجوانزين أحادى الفوسفات الحلقى في عضلات القضيب وزيادة مدة الانتصاب عن طريق تثبيط انزيم الفوسفوداى ايستريز,وهذه العقارات الموسعة للأوعية الدموية لما آثار وقائية على الأنسجة وخاصة الدموية. وقد استهدفت هذه الدراسة تقييم التأثير الوقائى لعقار الفردينافيل ضد التأثير السام لعقار الكولشيسين على خصى الجرذان الذكرية البيضاء البالغة حيث تم استخدام أربعون من هذه الجرذان قسمت الى أربع مجموعات متساوية، المجموعة الأولى مجموعة ضابطة تم اعطائها ا سم3 ماء مقطرعن طريق الفم و بر. سم3 محلول ملح تحت الجلد، المجموعة الثانية تم اعطاؤها ا مجم/ كجم من عقار الفردينافيل عن طريق الفم يوميا المجموعة الثالثة تم اعطائها هب بجم/ كجم من وزن الجسم تحت الجلد من عقار الكولشيسين يوميا, المجموعة الرابعة تم اعطاؤها هب مجم/كجم من وزن الجسم تحت الجلد من عقار الكولشيسين مع اعطاء ا مجم/ كجم من عقار الفردينافيل عن طريق الفم يوميا وكانت هذه الدراسة لمدةمب يوم وعند فهاية الدراسة تم وزن الجرذان ثم ذبحها لاستخراج الخصى والبرابخ وتم وزن الخصى وفحص الحيوانات المنوية البربخية من ناحية العدد ونسبة الحركة والحيوية وكذلك نسبة التشوهات وتم فحص الخصى بالميكروسكوب الضوئى والميكروسكوب الالكترونى.

واثبتت النتائج أن أعطاء عقار الكولشيسين أدى الى وجود انخفاض ذو دلالة احصائية في عدد ونسبة الحيوانات المنوية المتحركة والحية

بينما وجدت زيادة ذات دلالة احصائية في نسبة التشوهات في الحيوانات المنوية عند مقارنتها بالمجموعة الضابطة. لم يحدث تغير ذو دلالة احصائية في كل من وزن الجرذان أو وزن الخصى بعد أعطاء عقار الكولشيسين. من ناحية أخرى أوضحت الدراسة الهستوباثولوجية وجود تغيرات بالخصى مثل تلف ونقص فى الخلايا المنوية مع أضطراب وأزدياد سمكالغشاء القاعديوانكماشبعضالأنابيمع وجود بعض حطام الخلايا بتجويفهاوتوقف عملية انتاج الحيوانات المنوية في بعض الأنابيب واحداث بحاويف داخل وبين الخلايا المنوية,وانحلال فالميتوكوندرياوعندأعطاءعقار الفردينافيل مع عقار الكولشيسين أدى المى تحسن ذو دلالة احصائية في صورة زيادةعدد ونسبة حركة وحيوية الحيوانات المنوية ونقص نسبة التشوهات بها عند مقارنتها بالمجموعة الضابطة، كما حدث تحسن ف الصورة الهستولوجية للخصى. مما سبق نستخلص من هذه الدراسة أنعقار الفردينافيل له قدرة على تلطيف التأثير السام لعقار الكولشيسين على الخصى. 